\title{
Physical Education Teacher's Understanding of the Learning Model Personal Social and Responsibility
}

\author{
$1^{\text {st }} \mathrm{Mu}$ 'arifin \\ Physical Education Health and \\ Recreation Department \\ Universitas Negeri Malang \\ Malang, Indonesia \\ muarifin.fik@um.ac.id
}

\author{
$2^{\text {nd }}$ Febrita Paulina Heynoek \\ Physical Education Health and \\ Recreation Department \\ Universitas Negeri Malang \\ Malang, Indonesia \\ febrita.paulina.fik@um.ac.id
}

\author{
$3^{\text {rd }}$ Ari Wibowo Kurniawan \\ Physical Education Health and \\ Recreation Department \\ Universitas Negeri Malang \\ Malang, Indonesia \\ ari.wibowo.fik@um.ac.id
}

\begin{abstract}
- collection of information related to the understanding of Physical Education teachers on the Teaching Personal Social and Responsibility learning model so that researchers can develop this learning model which aims to improve students' social skills through Physical Education teachers who apply affective and cognitive aspects to the learning process of Physical Education. This research uses descriptive quantitative method. The results of the collection of information data regarding the understanding of Physical Education teachers at all levels in East Java Province stated that $72 \%$ of Physical Education teachers had attended PPG. All Physical Education teachers said they needed to develop social skills with a $100 \%$ percentage. Teachers who have applied social skills in the learning process are $87 \%$. There are as many as $30 \%$ of the teachers already know the TPSR learning model and $24 \%$ of the teachers state that they have implemented it. Then as many as $96 \%$ of the teachers agreed if the researchers developed the TPSR learning model and according to them the TPSR learning model could be applied in Physical Education learning in all activities that were in accordance with KI / KD. learning model is Teaching Personal and Social Responsibility very suitable to be applied in Physical Education because it can train students to be more responsible and confident, as well as train students to work with other students.
\end{abstract}

Keywords-Physical activity, social skills, students Teaching Personal and Social Responsibility.

\section{INTRODUCTION}

Education is indeed an important point in shaping the character of students through the implementation of character education in schools. Physical Education teachers need an appropriate learning model, not only for the development of motor skills, but also for the development of student character. One learning model that applies character education is Teaching Personal and Social Responsibility (TPSR). The TPSR model was developed by Don Hellison, who has grown rapidly since 1986. TPSR is a learning method model that is usually used to carry out the Physical Education learning process [1]. This approach occurs when the teacher establishes a relationship with students and then encourages students to establish and develop relationships with other students. The goal is to change or shape the character of students.

TPSR focuses on students to achieve the main goal of increasing student responsibility and confidence in their ability to perform specific tasks. This learning model is very suitable to be applied in Physical Education because it can train students to be more responsible and confident, and train students to work with other students. This model is usually used to foster student discipline (self-responsibility), for this reason this model is commonly used in schools that have problems with student discipline.

In Indonesia, there are currently not many studies that reset and identify the TPSR learning model. Therefore, the researcher wants to develop and identify the TPSR learning model which aims to make this learning model more recognized by Physical Education teachers. So far, most Physical Education teachers have only focused on psychomotor aspects without applying affective and cognitive aspects. In fact, according to (Bambang Abduljabar, 2014) says that Physical Education is a component of education capable of covering aspects of education as a whole. By introducing the TPSR learning model, it is hoped that Physical Education teachers will be able to apply 
it in order to build the character of the nation's successor [2].

Therefore it is necessary to collect information related to the understanding of Physical Education teachers on Teaching Personal Social and Responsibility learning models so that researchers can develop this learning model which aims to improve students' social skills through Physical Education teachers who apply affective and cognitive aspects to the learning process of Physical Education.

Teaching Personal and Social Responsibility (TPSR) is a learning model that has a main objective aspect of self-leadership and developing strategies for effective interpersonal relationships [3]. Teaching Personal and Social Responsibility learning model is a model that emphasizes the affective aspect as a more dominant aspect in the learning program through physical activities without neglecting other aspects of assessment, such as cognitive and psychomotor. The purpose of the Teaching Personal and Social Responsibility learning model as a medium for students in developing affective attitudes that are directed in the context of Physical Education. The results of this affective development can not only be developed at school, but outside the school as the main provision of students in social life, and of course to foster an attitude of personal and social responsibility that comes from oneself. Helliosn said that the Teaching Personal and Social Responsibility (TPSR) learning model has a character level mapping consisting of level zero to level five [4]. According to Hellison (2010: 27), TPSR has learning steps or learning syntax which consists of 5 steps [3].

\section{A. TPSR Characteristics}

According to Escarti, et al (2010: 668), the Teaching Personal and Social Responsibility Learning Model has characteristics, including: a) self confidence; b) redefine success; c) Enlisting social resources; d) Self-regulatory Learning; e) Self Regulatory Efficacy; f) Social Self-Efficacy [5]. Another feature of the Teaching Personal and Social Responsibility learning model is the mapping of character levels which is studied by paying attention to the characteristics of junior high school students. Mapping the character levels, among others (Desmita, 2009: 36; Hellison, 2010): a) Level 0, Irresponsibility; b) Level 1, Respect; c) level 3, Participation; d) Level 4, Self-direction; e) Level 5, Caring; f) Level 6, Cooperation [6].learning model Teaching Personal and Social Responsibility also has other characteristics, namely there are steps or stages of learning (Syntax). According to Hellison (2010: 27), the learning steps include: a) Relational Time; b) Awareness Talk; c) Physical Activity; d) Group Meeting; e) Self-reflection Time.

\section{METHODS}

\section{Research method}

This research uses quantitative descriptive method.

\section{Research Sites}

The research was conducted at Elementary School, Junior High School and Senior High School in East Java.

\section{Type of Data}

The types of data used in this study are descriptive data and quantitative data. Descriptive data is in the form of data containing descriptions of sentences, while quantitative data is in the form of numbers. Descriptive data were obtained from distributing questionnaires as a preliminary study on Physical Education, sports and health teachers in Elementary School, Junior High School and Senior High School in East Java and evaluation of experts. Quantitative data is obtained from the results of small group trials in the form of a questionnaire given and filled out by development research subjects.

\section{Data Collection Instruments}

Data collection in this development research uses Focus Group Discussion (FGD) to obtain data from experts and online-based questionnaire instruments to obtain data from test subjects for Physical Education, sports and health educators. Thus, the use of research instruments is to find complete information about a problem and social skills.

In order to get a satisfactory research result, the researcher compiled a lattice design of the research instrument. The grid aims to show the relationship between the variables under study and the data source or theory taken [7].

\section{Characteristics of the subject}

The subjects of the study were teachers of Physical Education Elementary School, Junior High School and Senior High School teaching in the East Java region. The number of Physical Education teachers who filled out the online questionnaire was 121 with 12 respondents coming from outside the city and being ignored. Based on the calculation, the sample required is 30 samples. The selection of research subjects was carried out by random sampling (randomly) and Isendental Planning (the subjects encountered were sampled).

There were 78 research subjects (teachers) in this study whose data collection instrument was an online questionnaire to collect information about the understanding of Physical Education teachers at all levels in East Java Province. The results of data collection will be described in accordance with the questions asked in the online questionnaire. The results can be described as follows:

1)The level of schools taught 


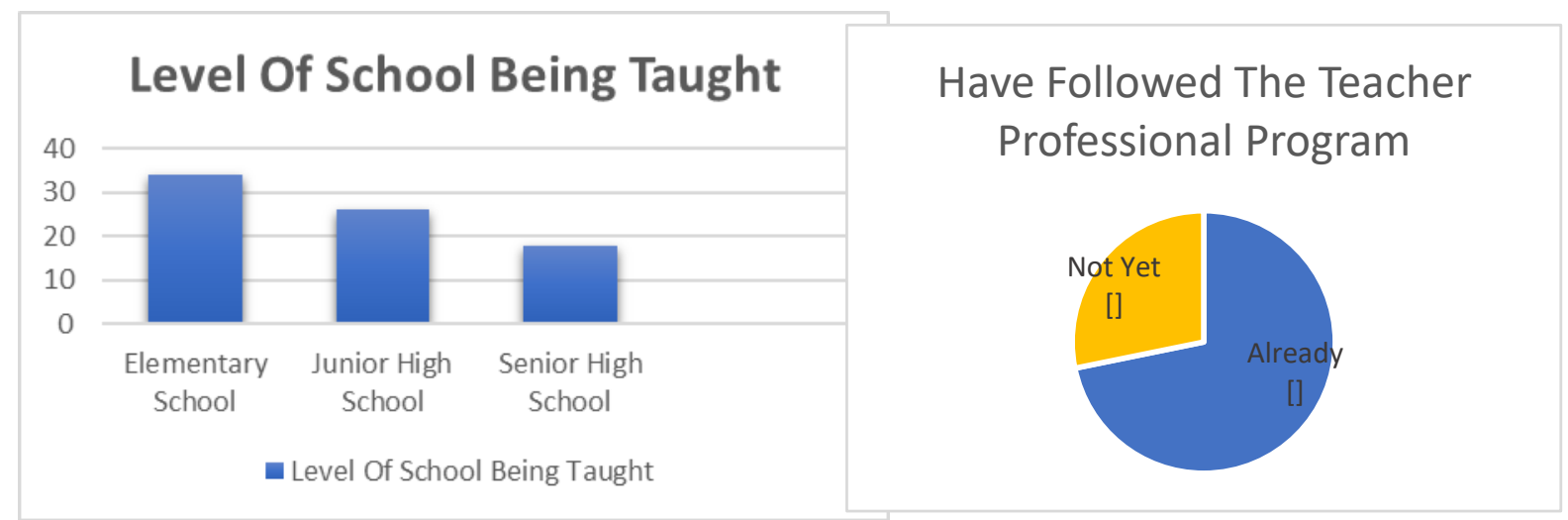

Fig. 1 The level of schools taught

Elementary School $=34$ people, Junior High School $=$ 26 people, Senior High School $=18$ people.

From 78 research subjects: 34 research subjects were Physical Education teachers at the Elementary School levels; 26 research subjects were Physical Education teachers at the Junior High School levels; and 18 research subjects were Physical Education teachers at the Senior High School levels. These data indicate that the subjects of study this were teachers of Physical Education at the Elementary School, Junior High School and Senior High School teachers in East Java Province.

\section{2)Length of teaching}

Diagram 2 Length of teaching

\section{Teaching Time}

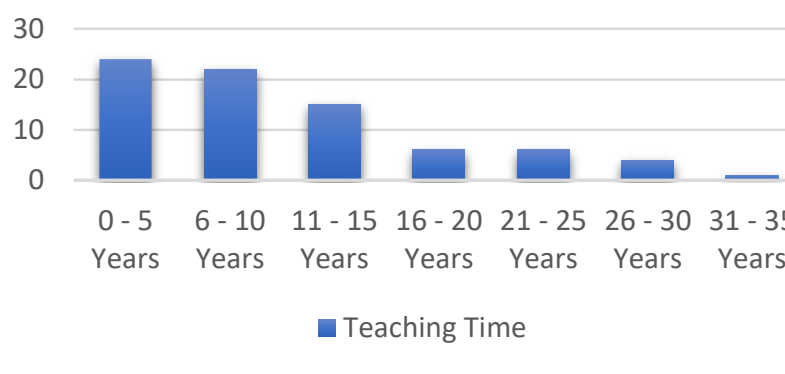

Fig 2. Teaching time

The data in the results section shows the length of teaching the research subject has. The data can be classified as follows: 24 people have taught for $0-5$ years; 22 people have taught for 6 - 10 years; 15 people have taught for 11-15 years; 6 people have taught for 16-20 years; 6 people have taught for $21-25$ years; 4 people have taught for 26-30 years; and 1 person has taught for $30-35$ years.

\section{3) Already following the Teacher Professional Program}

Fig. 3 Already following the Teacher Professional Program

Table 1 tabulation of respondents' answers to questions about the application and knowledge of social skills with the TPSR model.

\begin{tabular}{|c|c|c|}
\hline \multirow{2}{*}{$\begin{array}{c}\text { Number of } \\
\text { Questions }\end{array}$} & \multicolumn{2}{|c|}{$\mathbf{n}(\%)$} \\
\cline { 2 - 3 } & Yes & No \\
\hline 1 & $30(100 \%)$ & $0(0,0)$ \\
\hline 2 & $25(83,3 \%)$ & $5(16,67 \%)$ \\
\hline 3 & $10(33,33 \%)$ & $20(66,67 \%)$ \\
\hline 4 & $8(26,67 \%)$ & $22(73,33 \%)$ \\
\hline 5 & $30(100 \%)$ & $0(0,0)$ \\
\hline 6 & $29(96,67 \%)$ & $1(3,33 \%)$ \\
\hline
\end{tabular}

Respondents' answers to the question (1) whether there is a need for social skills development $100 \%$ answered necessary, (2) whether the Physical Education teachers have used social skills from 30 samples, around $83.33 \%$ answered yes and $16.67 \%$ answered no, (3) whether Physical Education teachers already know the TPSR learning model, around $33.33 \%$ know the TPSR model and $66.67 \%$ don't know yet, (4) whether Physical Education teachers have implemented the TPSR learning model from 30 samples $26.67 \%$ answered that they have applied and $73.33 \%$ have not apply (5) do agree if the TPSR model is developed, the respondents $100 \%$ answer agree, (6) whether the TPSR model can be applied to all activities in Physical Education that are in accordance with KD from 30 samples $96.67 \%$ of respondents answered yes and $3.33 \%$ answered no. 6. Data Analysis

The data analysis technique used is descriptive quantitative data. The quantitative data is a percentage of the questionnaire data. The measurement technique used for data collection using the Likert scale aims to measure the attitudes, opinions and perceptions of a person or group of people about social phenomena [8].

The Likert scale instrument has an answer level that includes very positive to very negative. For the purposes of quantitative data analysis, answers can be given a predetermined score, namely one (1), two (2). Likert rating scale. 


\section{1) Instrument Validity Test}

The instrument validity test was conducted to show the validity of the instruments to be used in the study. Validity is a measure that shows the level of validity and validity of an instrument [7].

Table 2 Instrument Validity Test

\begin{tabular}{|c|c|c|c|}
\hline Number & $\mathbf{r}_{\text {count }}$ & $\mathbf{r}_{\text {table }}$ & statement \\
\hline 1 & - & 0,3061 & Not valid \\
\hline 2 & 0,643 & 0,3061 & Valid \\
\hline 3 & 0,889 & 0,3061 & Valid \\
\hline 4 & 0,866 & 0,3061 & Valid \\
\hline 5 & - & 0,3061 & Not valid \\
\hline 6 & 0,4 & 0,3061 & Valid \\
\hline
\end{tabular}

Based on the table above, data obtained from 6 questionnaire questions distributed online that 4 out of 6 questions are declared valid and 2 questions are declared invalid. 2 questions were declared invalid because of the lack of variation in answers. For 4 valid questions, it can be used as a data collection tool.

2) Instrument Reliability

Test Reliability test is conducted to determine the permanence of an instrument (measuring instrument) in measuring the same symptoms even at different times.

Table 3 Instrument Reliability

\begin{tabular}{|c|c|}
\hline \multicolumn{2}{|c|}{ Reliability Statistics } \\
\hline Cronbach's Alpha & N of Items \\
\hline .630 & 6 \\
\hline
\end{tabular}

The results of the online questionnaire question reliability test showed $r$ count $=0.630$. When seen in the table of the Correlation Coefficient Interpretation Guidelines above, that $r$ count is at the level of 0.7> $a \geqslant 0.6$ which states that the question on the reliability results is questionable.

\section{DISCUSSION}

The data in the results section shows that 56 research subjects have participated in Teacher Professional Program or Teacher Professional Education and Training while 22 research subjects have not attended Teacher Professional Program or Teacher Professional Education and Training.
A. What learning models do you often use in the Physical Education learning process?

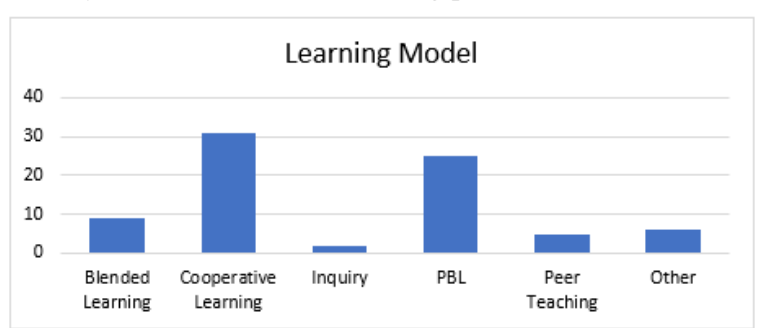

Fig 4. The Learning Models Used by Teachers

From the data in the results section, it can be concluded that 9 research subjects often use the Blended Learning model (technology-based learning), 31 research subjects often use the Cooperativemodel

Learning(group learning), 2 research subjects often use the Inquiry learning model, 25 research subjects often using PBL (Problem Based Learning) learning model problem-based problem solving, 5 research subjects often use Peer Tutoring learning model, and 6 research subjects often use other learning models.

B. What are the reasons you choose this learning model?

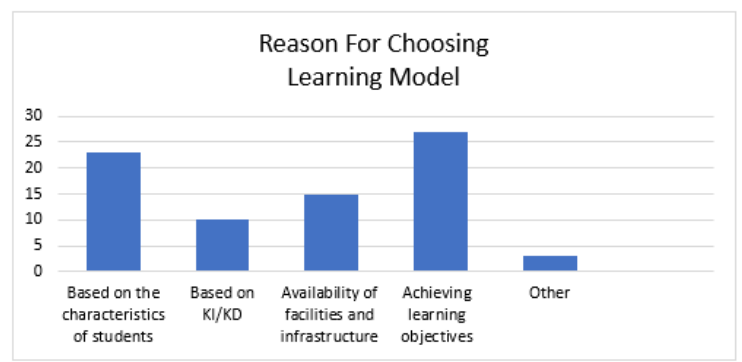

Fig. 5 Reasons for Choosing Learning Model

The data in the results section shows the reasons for the research subjects choosing the learning model mentioned above: 23 research subjects chose a learning model based on the characteristics of students, 10 research subjects chose a learning model based on $\mathrm{KI} / \mathrm{KD}, 15$ research subjects chose a learning model based on the availability of facilities and infrastructure, 27 research subjects chose a learning model based on the achievement of learning objectives, and 3 research subjects chose a learning model based on other reasons. 
C. What are the obstacles for you in implementing the Physical Education learning process with the learning model that you applied?

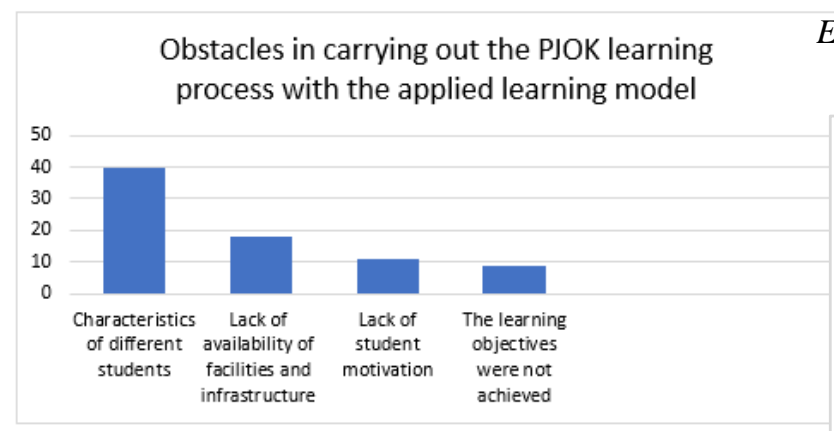

Fig 6. Obstacles in carrying out the PJOK learning process with the applied learning model

The data in the results section shows the constraints expressed by the research subjects, the results of these data include: 40 research subjects assessed that different characteristics of students were learning constraints; 18 research subjects assessed that the lack of availability of advice and infrastructure was a constraint to their learning; 11 research subjects assessed the lack of student motivation as an obstacle to learning; and 9 research subjects assessed that not achieving the learning objectives was a learning constraint.

D. Do you think teachers need to develop students' social skills?

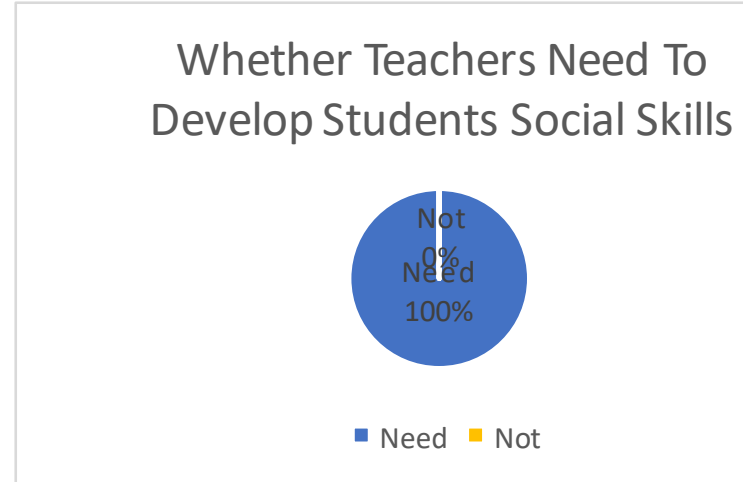

Fig. 7 Whether Teachers Need To Develop Students Social Skills

The data in the results section shows that the opinions of all research subjects are in line with the opinion of experts that social skills are not things that are formed suddenly, but are formed progressively by imitation and habituation which are influenced by the environment around a person whose goal is to achieve social acceptance [1 ]. This formation begins in the womb until death. Alignment between the opinions of all research subjects and expert opinions can be used as the basis for conducting studies aimed at developing the social skills of students in schools in East Java on Physical Education learning.

E. Have you implemented students' social skills development in learning Physical Education?

\section{Have You Implemented Students Social Skills Development in Learning Physical Activity?

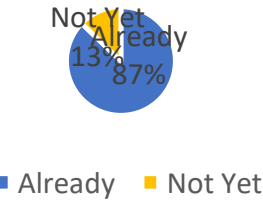

Fig 8. Implementation of students' social skills development in Physical Education learning

The data in the results section shows the results, among others: 68 research subjects have implemented social skill development in their learning; and 10 research subjects have not applied social skills to their learning. From the data above, it can be concluded that the application of the social skills development of students at all levels of school in East Java, especially in learning Physical Education has a good start but still needs to be improved because there are still a small number of Physical Education teachers at each level. have not implemented the social skills development of students in East Java Province.

F. Do you know the TPSR (Teaching Personal and Social Responsibility) learning model?

Do You Know The TPSR Learning Model

(Teaching Personal and Social Responsibility)

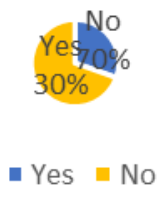

Fig 9. Knowledge of the TPSR (Teaching Personal and Social Responsibility) learning model?

The data in the results section shows the results, among others: 24 research subjects had known the TPSR learning model while 55 research subjects did not know the TPSR learning model. From the results of the data above, it can be concluded that the 
Physical Education teachers at all levels in East Java Province can be said to have no knowledge of the TPSR learning model.

G. Have you ever applied the TPSR (Teaching Personal and Social Responsibility) learning model?

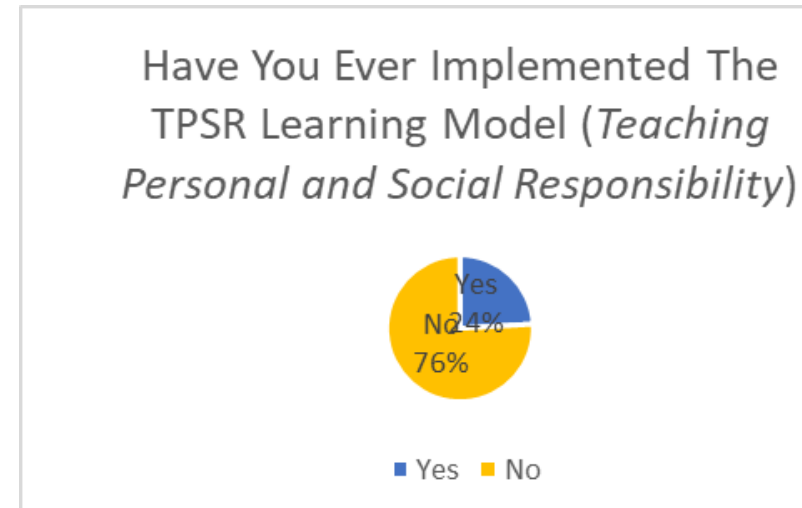

Fig 10. Implementation of the TPSR (Teaching Personal and Social Responsibility) learning model

The data in the results section shows the results, among others: 19 research subjects have applied the TPSR learning model in their learning while 60 research subjects have not applied the TPSR learning model. From the data above, it can be concluded that this data is fully related to the data in the previous question where because Physical Education teachers at all levels in East Java Province do not know the TPSR learning model, it is very possible for research subjects to mostly have not applied the TPSR learning model in their learning.

H. Do you agree if the researcher develops a TPSR

(Teaching Personal and Social Responsibility) learning model?

Do You Agree If The Researcher
Develops
A TPSR Learning Model
(Teaching Personal and Social...

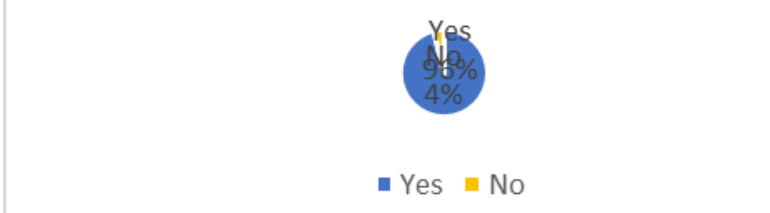

Fig 11. Approval if the researcher develops the TPSR (Teaching Personal and Social Responsibility) learning model

Based on the results of the related research review in the introductory chapter, there is still not much research on the theme of the TPSR learning model so it is in line with the results of gathering information through online questionnaires where it can be concluded that it is necessary to develop the TPSR learning model by researchers. The data in the results section shows the results: 76 research subjects approved the development of the TPSR learning model by the researcher and 3 research subjects did not agree to the development of the TPSR learning model.

I. According to you, can the TPSR (Personal Teaching and Social Responsibility) learning model be applied in learning Physical Education all activities that are in accordance with KI / KD?

\section{According To You, Whether The TPSR (Teaching Personal And Social Responsibility) Learning Model Can Be Applied In...}

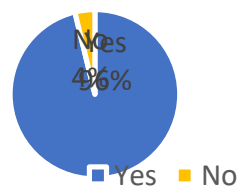

Fig 12. The TPSR (Personal Teaching and Social Responsibility) learning model be applied in learning

Physical Education all activities that are in accordance with KI / KD

The data in the results section shows that 76 research subjects agree with the researcher that the TPSR learning model can be applied in Physical Education learning to all activities that are in accordance with KI / KD while 3 research subjects disagree. Because most of the research subjects agreed with the researcher regarding the application of the TPSR learning model in Physical Education learning in all activities that were in accordance with $\mathrm{KI} / \mathrm{KD}$, it was concluded that it was necessary to develop this TPSR learning model.

\section{CONCLUSION}

To improve the character of students today, especially with regard to social attitudes, Physical Education teachers need a learning model that can shape student character. TPSR is a learning method model that is usually used to carry out the Physical Education learning process. This learning model is very suitable to be applied in Physical Education because it can train students to be more responsible and confident, and train students to work with other students. 
What distinguishes the TPSR model from other learning models is that there are steps or stages of learning. The learning steps include: a) Relational Time; b) Awareness Talk; c) Physical Activity; d) Group Meeting; e) Self-reflection Time.

Based on the results of gathering information about the understanding of Physical Education teachers at all levels in East Java Province. The results of the data collection stated that $72 \%$ of Physical Education teachers had attended Teacher Professional Program. All Physical Education teachers said they needed to develop social skills with a $100 \%$ percentage. Teachers who have applied social skills in the learning process are $87 \%$. There are as many as $30 \%$ of the teachers already know the TPSR learning model and $24 \%$ of the teachers state that they have implemented it. Then as many as $96 \%$ of the teachers agreed if the researchers developed the TPSR learning model and according to them the TPSR learning model could be applied in Physical Education learning in all activities that were in accordance with KI / KD.

\section{REFERENCES}

[1] G. Shirley, "Teaching Personal and Social Responsibility through Physical Activity (3Rd Edition)," New Zeal. Phys. Educ., vol. 44, no. 2, p. 30, 2011.

[2] B. Abduljabar., "Memperkokoh Pendidikan Karakter Melalui Mediasi Aktivitas Jasmani Berbasis Nilai," pp. 97-107, 2014.

[3] D. Hellison, Teaching personal and social responsibility through physical activity. Human Kinetics., 2010.

[4] D. Hellison, Teaching Responsibility Through Phisycal Activity. University of Illinois at Chichago: United States of America, 2003.

[5] D. Escartí, A., Gutiérrez, M., Pascual, C., \& Marín, "Application of Hellison's teaching personal and social responsibility model in Physical Education to improve self-efficacy for adolescents at risk of dropping-out of school," Span. J. Psychol., vol. 2, no. 13, pp. 667-676., 2010.

[6] D. Desmita, Psikologi perkembangan peserta didik. Remaja Rosdakarya, 2009.

[7] Arikunto, Prosedur Penelitian Suatu Pendekatan Praktek. Jakarta: Rineke Cipta, 2006.

[8] Sugiyono., Metode Penelitian Pendidikan. Bandung: Alfabeta, 2015. 